\title{
SAWAH DILAHAN PERTANIAN MASYARAKAT SEBAGAI SUMBER KEHIDUPAN DALAM RUANG LINGKUP KOMUNIKASI LINGKUNGAN
}

\author{
MONIKA SARI \\ 1920701022 \\ KOMUNIKASI LINGKUNGAN
}

ILKOM A (2019)

Masyarakat sesederhana apapun masih bersifat dinamis yang sewaktu-waktu dapat berubah seiring perkembangan zaman. Termasuk juga masyarakat petani yang dalam kehidupannya tidak bisa lepas kaitannya dengan tanah/lahan. Oleh sebab itu, sekecil apapun perubahan yang ada kaitannya dengan lahan dapat membuat perubahan-perubahan dalam masyarakat petani.

Alih fungsi lahan pertanian tidak hanya menyebabkan berkurangnya tenaga kerja bidang pertanian yang berpengaruh pada produksi komoditas, namun juga memberi dampak pada kehidupan sosial di masyarakat. Dikutip dari jurnal artikel(Cimanuk and Pandeglang 2016) Lahan bagi petani tidak hanya bernilai ekonomi namun juga sosial. Keterikatan antara lahan pertanian dan petanimenumbuhkan berbagai kearifan lokal yang mulai luntur seiring dengan berkurangnya lahan pertanian .

Ketersediaan lahan pertanian yang semakin berkurang membuat aspek-aspek sosial dalam masyarakat ikut berubah seperti halnya modal sosial. Hal ini sangat disayangkan karena komponen-komponen modal sosial di dalam masyarakat seperti jaringan, norma dan kepercayaan merupakan bagian dari kehidupan sosial yang mendorong tindakan kolektif secara lebih efektif untuk mencapai tujuan-tujuan bersama. 
Pada masyarakat tradisional, keberadaan lahan/tanah sebagai sumber kehidupan dimuliakan dan dihormati oleh masyarakat. Hubungan yang ada antara manusia dengan tanah tidak hanya sebagai hubungan antara orang dengan alat-alat produksi. Penghormatan terhadap tanah semakin berkurang pada masyarakat petani yang sudah maju.

Seperti pendapat dari jurnal artikel yang dibuat oleh (Yenrizal, Rahmat, and Iskandar 2015) Pemaknaan simbolik manusia mengenai lingkungannya merupakan titik tekan utama dalam keilmuan komunikasi, terutama komunikasi lingkungan. sehingga simbol simbol dari lingkungan alam dapat dimaknai dan memiliki arti tersendiri. Masyarakat semende, sawah dimaknai masyarakat bukan semata mata tanaman ekonomis, yang hasilnya menjadi patokan ekonomi keluarga. Sawah lebih identik sebagai bentuk ketahanan pangan masyarakat. Ini diperkuat dengan indikasi yang tampak bahwa pemanfaatan hasil sawah tidak untuk dijual. Padi hasil panen digunakan untuk tiga hal, yaitu bahan makanan pokok sekeluarga besar selama satu tahun, bahan bibit untuk musim tanam yang baru, dan cadangan apabila ada hajatan dalam keluarga. Sisa dari pembagian ini, barulah dijual.

Dalam jurnal artikel (Yenrizal, Rahmat, and Iskandar 2015) Penelitian ini berhasil menarik benang merah bahwa pemaknaan masyarakat terhadap fenomena lingkungan, terutama kegiatan bersawah, menghasilkan tiga makna simbolik dari sawah, yaitu sebagai simbol kesejahteraan, simbol kekuasaan, dan simbol identitas. Masing-masing pemaknaan ini memiliki kontribusi besar terhadap tatanan kehidupan masyarakat yang sampai saat ini tetap bisa hidup berdampingan dengan lingkungan alam. Mekanisme bersawah yang dilakukan warga dengan pola satu kali setahun adalah bentuk pemahaman terhadap fenomena lingkungan, keseimbangan ekologis dan sistem sosial, alih-alih bukan bentuk ketertinggalan atau keengganan untuk berubah. Semua hal itu terjadi dalam sebuah aktivitas proses komunikasi lingkungan yang sesuai dengan struktur sosial masyarakat, dengan berlangsungnya mekanisme simbolik yang berlangsung secara rutin dan alamiah.

\section{Sektor pertanian menjadi sumber kehidupan masyarakat}

Sektor pertanian merupakan sumber kehidupan manusia dan juga sektor yang menjanjikan bagi perekonomian Indonesia. Pertanian salah satu pilar bagi 
kehidupan bangsa. Bertani adalah pekerjaan yang mulia, selain untuk kehidupannya sendiri, juga penting bagi kelestarian alam dan makluk hidup lainnya.

Petani sebenamya manusia yang kaya karena bisa memberikan banyak hal yang bermanfaat bagi manusia dan alam. Menjadi petani adalah membanggakan dan ladang amal untuk kehidupan nantinya. Kemauan untuk belajar dan berusaha serta menerapkan inovasi teknologi pertanian adalah kunci suksesnya.

Dengan kegiatan di sektor pertanian,masyarakat memperoleh pangan yang merupakan kebutuhan pokok untuk keberlanjutan hidup dan kehidupannya. Manusia tidak dapat hidup dengan baik tanpa makan yang berkecukupan baik jumlah dan mutunya. Oleh karena itu kemampuan negara atau daerah untuk menyediakan pangan yang cukup bagi penduduknya melalui kemandirian pangan adalah kewajiban.

\section{Kesimpulan}

keberadaan lahan/tanah sebagai sumber kehidupan dimuliakan dan dihormati oleh masyarakat. Hubungan yang ada antara manusia dengan tanah tidak hanya sebagai hubungan antara orang dengan alat-alat produksi. Penghormatan terhadap tanah semakin berkurang pada masyarakat petani yang sudah maju.

\section{DAFTAR PUSTAKA}

Cimanuk, D I Kecamatan, and Kabupaten Pandeglang. 2016. "Alih Fungsi Lahan

Dan Perubahan Masyarakat Di Kecamatan Cimanuk, Kabupaten Pandeglang." https://iournal.ipb.ac.id/index.php/sodality/article/download/23465/16419

Yenrizal Y, Kabupaten Muara Enim-sumatera, Agus Rahmat, and Johan Iskandar. 2015. "SEMENDE DARAT TENGAH" 5 (3): 287-97.

http://banten.litbang.pertanian.go.id/new/index.php/publikasi/koran/218-pertanian-sumberkehidupan 